\title{
EMPIRICAL INVESTIGATION OF THE RELATIONSHIP BETWEEN ISLAMIC CONCEPT OF AL-RAJA (HOPE) AND HIGHER INSTITUTION STUDENTS' MENTAL WELL BEING
}

\author{
Uswatun Hasanah \\ Sri Nurul Milla \\ Ismail Abdul Fatai \\ International lslamic University Malaysia \\ sn.milla307@gmailcom
}

\begin{abstract}
The present research is an attempt to investigate the relationship between the concept of alRaja (hope) as spiritual aspect in Islamic worldvlew and mental well-being. The study employs quantitative research method where 1045 higher institutions students were surveyed through administration of questionnaire. The Pearson moment correlation analysis was conducted with SPSS version 21 to investigate the relationship. The finding from the analysis shows that there is significant positive correlation between Islamic concept of al-Raja (Hope) and student's mental well-being. The study provides implication for religious Islamic religious adherents as well as Muslim psychotherapist to see the Islamic concept of Raja as a factor that can boost individual mental state.
\end{abstract}

Keywords: Mental heolth, well-being, al-raja (hope)

\section{INTISARI}

Penelitian ini merupakan satu upaya untuk menyelidiki hubungan antara konsep al-raja (harapan) sebagai aspek spiritual menurut pandangan islam dan kesejahteraan mental. Penelitian ini menggunakan metode kuantitatif. Sebanyak 1045 mahasiswa mengisi kuesioner yang telah disusun. Penelitian ini menggunakan analisa korelasi produk momen Pearson. Hasil analisa menunjukkan bahwa ada hubungan positif yang signifikan antara konsep al-raja(harapan) dan kesejahteraan mental kesejahteraan subjek. Hasil penelitian ini memberikan implikasi baik untuk pemeluk agama islam atau psikoterapis muslim untuk melihat konsep al-raja sebagai faktor yang dapat meningkatkan kondisi mental individu.

Kata kunci: al-raja (harapan), kesejahteraan, mental

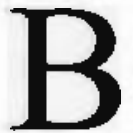

eing a university and college students demands many new life skills to master. Those are skills to fulfil the demand of being students in higher institution as well as skills to be an individual who start living a life more independently. This new chapter of life comes with expectations both from self and environment such as the institution and social groups the students belong to.
However, the reality of every stage of life including a college life mostly does not appear as what being expected. There are times when students have up and down life series, face hardship, trials, and calamity either with their personal and student life. Experiencing life that is away from what being expected can potentially lead to maladjustment life and even to mental health issue such as fear, anxiety, 
depression, etc. Nevertheless, the students can benefit and learn a lot from them such as strengthening their mental well-being and even helping them to be a better person by being positive and hopeful over the hardship and trial they experience. Because it is believed that the hardships experience comes along with the lesson and wisdom if they have been dealt accordingly. Being hopeful is one of the key factors that enable the individuals to stand up firmly across the period trial which consequently boost their mental health.

Al-Raja (hope) in Islam means optimism of the mercy of Allah; it is the contemplation on the promise of reward in this world and in the hereafter from Allah. Muslims hope for Aliah's mercy and His reward. The word of hope and several aspects related to it have been documented in the Quran. The Aimighty God has stated in the Quran chapter 2 verses 218:

"Indeed, those who have believed and those who have emigrated and fought in the cause of Allah those expect the mercy of Allah. And Allah is Forgiving and Merciful."

It is also mentioned in the Quran that hope equally mentioned as the antidote to depression, sadness and other mental health problem. As Allah says in the Qur'an

"O My slaves who have transgressed against themselves (by committing evil deeds and sins)! Despair not of the Mercy of Allah, verily Allah forgives all sins. Truly, He is OftForgiving, Most Merciful:" (Surah Az-Zumar 39:53)

When Allah says man should not despair of His mercy, one can say that expectation of Allah's mercy will bring about joy and happiness and word off fear, anxiety and depression. Therefore the present study wishes to employ the concept of hope in Islam as it is related to mental well-being scientifically to higher institution students.

The concept of hope is seen as universal paradigm which has a strong influence on human being (Moore, 2005). Hope in general terms is defined as the expectation of positive outcome in the period of tribulation or trials (Davidsonarad et al. 2013). It is also seen as the individual perception that goals and objectives can be achieved (Snyder et al., 1991). Equally, (Feldman \& Kubota 2015), proposed that hope is "a cognitive set that is based on a reciprocally-derived sense of successful agency (goal-directed determination) and pathways (planning to meet goals) (p. 571) A state-trait theory of hope proposes dispositional hope as a general cognitive set applying across a range of situations and relatively stable across time, whereas state hope varies according to particular times and situations. People with higher dispositional hope should endorse higher state hope as they confront situations compared to persons with low dispositional hope (Snyder et al, 1996). Based on the various definitions above meanings of hope can be summed up as the optimistic expectation of positive outcome when human being is passing through trials of all kind but during the period of ease it is seen as the human perception that goals and objectives that could be achieved.

Hope in Islamic perspective is illustrated in various situations. The hope for Mosiem is as manifestation of his belief to his Lord which derived from his knowledge about Allah the Almighty. According to al- junaid quoted in the alGhazoli believed that the experience of 
difficulties in life can soften the heart to savour the sweetness of intimate communing (al-munajat) and to benefit the effect of remembrance of Allah (dhikr). According to him the states of heart in the period of trial and tribulations is where the heart is close to the door of knowing the divine knowledge.

Knowing the qualities that belong to Allah will sustain the person who face with hardship, at the same time he put hope over Allah's mercy which in turn help him to stand firmly in that difficult situation. On the other hand, being hopeless can lead to a total distraction as a saying narrated by bon Mas'ud:

"Total destruction is caused by two things: hopelessness and conceit. "He apporently put the two together because the hopeless person does not seek pleosure because of his hopelessness; whereas the conceited does not seek it thinking he has already has it."

in addition, al-Ghazali asserted that whenever fear overcomes the self, it has to mix with hope. The prophet SAW said "none of you should die except that he has good expectation from his Lord. Equally, the companion Umar bin Khattab (RA) said "when a person approaches death, having hopes and good expectation from his Lord is much better".

Al imam Abu Hamid al-Ghozali mentioned that act of worship which performed because of hope is much better compared to the worships performed out of fear. it is understood that hope necessitates love. In contrast to hopeless, that leads to destruction. Moreover, the hope is transcendent of patience over the calamity that comes across in someone's life. The almighty Allah says "We do indeed know how thy heart is distressed at what they say. But celebrate the praises of thy Lord, and be of those who prostrate themselves in adoration." (Al-Hijr, 15:9798) ". The hadith of the prophet SAW also supports the necessity of being patient in facing the hardship and difficulties for the hoping of Allah mercy. As the prophet said:

"Allah the Almighty said: "When I rest my servant with a calamity and he patiently endures it without complaining to those who visit him, I give him new flesh better than the flesh he had before. If $i$ make him recover, I make him recover without any sins and if I make him die, I embrace him in my mercy."

It can be concluded from these two hadiths that being patient with all difficulties considered the indication of being hopeful that Allah will replace those calamitles with better things as well as mercy of Allah. Being optimistic and hopeful is also the expression of belief in Allah, love, firm, and truthf ul as He is the best sustainer. He clearly revealed in the Quran the quality of those individuals:

Allah also says: "It is not righteousness that ye turn your faces Towards east or West; but it is righteousness- to believe in Allah and the Last Day, and the Angels, and the Book, and the Messengers; to spend of your substance, out of love for Him, for your kin, for orphons, for the needy, for the wayfarer, for those who ask, and for the ransom of siaves; to be steadfast in prayer, and practice regular charity; to fulfil the contracts which ye hove made; and to be firm and patient, in pain (or suffering) and adversity, and throughout all periods of panic. Such are the people of truth, the Allah-fearing. "(al-Baqarah, 2:177) 
Referring to the Quranic verses, hadiths of the prophet SAW and assertions from al-Ghazali, it can be summed up that those who live a life with hope for success and face the pain and hardship out of love, patience, reliance upon Allah and belief in Him are indicating the healthy state of their spirituality which consequently can uphold their mental health. In addition, al-Ghazali affirmed that these qualities only can be obtained through gaining the knowledge of Allah and action out of the messages revealed.

Hope is an important phenomenon to all people across the lifespan. The experience of hope is important in everyday life and especially while coping with a highly stressful life (Hasson-ohayon et al, 2009). It has been identified it as integral to the profession of psychiatry as well as counseling important for initiating therapeutic change, willingness to learn and personal well-being (Schrank et al. 2012). Recently, hope has also become a focus for mental health practice and research (Schrank, Stanghellini, \& Slade, 2008).

Hope is considered central to the concept of personal recovery from mental disorders, both as a trigger and as a maintaining factor, since it helps people to find the courage to stat their recovery journey and the motivation to keep working on recovery despite potential obstacles (Bonney \& Stickley, 2008). Hope is also essential for resilience (Ong. Edwards, \& Bergeman, 2006), and consistently identified by both patients and therapists in various settings as a key factor in psychotherapy (Schrank et al., 2008). Hope is considered a basic personality trait (Snyder et al., 1991) and resource in human life (Kylma, 2005), as well as a healing force promoting wellbeing (Holdcraft and Williamson, 1991). Hope has been found to contribute to therapeutic efficacy and is consistently identified as an essential element for recovery from MI (Werner 2012).

Meanwhile several studies have shown that hope is considered to be an important factor in recovering from mental illness (Van Gestel-Timmermans et al., 2010) and is believed to improve the quality of life of people with schizophrenia (Hasson-Ohayon et al., 2009). Equally, findings among parents of children with chronic illnesses or with a mental or physical illness show that those parents with high levels of hope suffer less depression, stress, and physical and mental exhaustion than their less hopeful peers, and are better able to devise ways of solving prob-lems (e.g. Kashdan et al, 2002; Levanon-Simyoni, 2009; Venning. Eliott, Whitford, \& Honnor, 2007).

In 2006, Kylma et al, provided an integrative review of the current status of research on hope and schizophrenia, using content analysis to examine 17 relevant published articles. Findings indicated that hope is a positive factor in the lives of individuals living with schizophrenia, their significant others, and their healthcare personnel. In addition to identifying factors associated with and contributing to hope in individuals living with schizophrenia, Kylma et al. identified hope-engendering interventions and treatment evaluation with regard to hope for this population. In a later review, Kylma et al. (2009) provided an integrative review of the current status on hope in palliative care, using content analysis to examine 34 relevant published articles on hope. Findings suggested at least two overarching themes of patients" 
hopes: a) "living with hope," and b) "hoping for something," Kylma et al. concluded that hope is important in both living and dying.

More so, (Werner 2012), conducted an empirical research to examine a mediation model for the relation between hope and SWB among individuals with serious mental illness [SMI]. Face-to-face structured interviews were conducted with 172 individuals with SMI. Instruments included the Personal Well-being Index, the Hope Scale, and the Camberwell Assessment of Needs. Hope and needs were predictive or $40 \%$ of the variability in SWB, with hope being a stronger predictor. Having no needs was positively predictive of SWB, while total number of needs was negatively predictive or SWB. It can be seen that hope is a very useful means for combating mental illness and upgrading mental well-being.

However, the hope scale uses in the past literatures are conventional, secular and western oriented hope scale which might not be effective for people who professes a religion or the other. Therefore, the present research intends to investigate from Islamic perspective by using the Islamic hope scale to determine the relationship between the Islamic concept of hope and mental well-being.

\section{METHODS}

\section{Population of the Study}

Population in study refers to the total number or people, things and events intended to be investigated (Sekaran \& Bougie 2010). Theref ore, the population of the current research is the entire undergraduate students in International Islamic University Malaysia (IIUM). The researcher is interested in the higher institution students because it is the major and prominent higher institution in Malaysia which provides standard of institutional facilities for students and most students from every part of Malaysia schools in IIUM.

\section{Sampling Procedure}

The sampling design to be adopted for the present research is the purposive non-probability sampling. It is the process of obtaining Information from a particular target group who are able to provide the required information, it could be that they are the group that possess the information required or they meet up with some criteria set by the researcher (Sakaran \& Bougie 2010). The selected sample from the present study meet up some criteria set for the study. That is, they are higher institution student studying in Malaysia. These are the criteria that made the respondent fitted for the study.

\section{Sample Stze}

The present study Is covering a quite large population and the issue somehow complex, based on this the researcher decided to use larger sample size as compared to the normal sample calculation procedures. One of the prominent methods of determining sample size is the Krejcieu and Morgan's sample size determination. If we are to go by this, from roughly 15,000 undergraduate students the normal sample size required is 375 according to sample size calculation. However, based on the objective of the present study the researcher has decided to use 1200 students' participants, in order to have a robust data and make a reliable generalization. This is because the general rule according to Creswell (2008) in 
selecting sample is that the larger the samples the less possible error that such sample could be differ from the population.

\section{Instrumentation}

This aspect is about the instrument used for the collection data in this study. In this sense the instruments used for the present research are already existing scales, some of which are adapted from the original sources. These instruments are already standardized one which have been validated and use by different authors. In order to measure the dependent variable which is the mental well-being, the Warwick Edinburg mental well-being scale is adapted for the present study. This scale is mostly used by scientist and psychologists. It was developed by researchers from Warwick Edinburg University (Lundgren- Nilsson, Jonsdottir, Ahlborg, \& Tennant, 2013). More so, the independent Hope Scales are adapted from Religious Orientation scale by Gorsuch \& Mcpherson (1989) and Religious Commitment scale by Pfeifer \& Waelty (1995). These religious scales were thoroughly adapted and some items are equally added to feet in to the setting and the respondents of the research.

Based on this, the quantitative instrument used for the research is divided into two main sections. The first section provides the demographics Information of the respondents such as: gender, age, year of study and faculty. The researcher use five point likert scale to assess the level of strength a subject is having in terms of agree and disagree and to calculate the summated scores for each of the sample by adding all the items (Sekaran \& Bougie 2008), this scales cover the items such as: strongly disagree (1), disagree (2), Neutral
(3), agree (4) and strongly agree (5). The highest score for the present study will be 5 while the lowest score will 1. Equally, all the negatively worded items from the previous instrument adapted are changed to positive for easy analysis.

\section{Procedure for Data Collection}

The major participants this research are students from higher institutions precisely undergraduate students. When the questionnaire is ready the researcher distributed the questionnaires on faculty bases, including both males and females. It is expected that the majority of the respondents filled the questionnaire on the spot and return it to the researcher immediately. This is due to the fact that the language of the questions is very straightf orward and easy to understand. in all 1250 questions will be distributed and 1045 are expected to be returned. The researcher personally distributes the questionnaire.

\section{RESULT}

The relationship between mental wellbeing and the islamic concept of Hope construct was measured using SPSS version 21 with Pearson product moment correlation coefficient. The preliminary analysis was performed to ensure that there is no violation of the assumption of normality, linearity and homoscedasticity. There was a strong positjve significant correlation between the two variables, $r=$ $.400, \mathrm{n}=1045, \mathrm{p}=<.0001$, with higher level of mental wellbeing associated with a bit lower level of hope. This result shows that the islamic concept of Hope (Ar-Raja) could positively influence individual mental wellbeing. The result can be vividly view from the table below. 
Table 1. Descriptive Statistics

\begin{tabular}{cccc}
\hline & Mean & Standar Deviation & N \\
\hline Mental Well Being & 54,4995 & 7,68185 & 1045 \\
Hope & 31,0842 & 4,35874 & 1045 \\
\hline
\end{tabular}

Table 2. Correlations

\begin{tabular}{cccc}
\hline & & Mental Well Being & Hope \\
\hline Mental Well Being & Pearson Correlation & 1 & $0,400^{*}$ \\
& Sig. (2-tailed) & & 0,000 \\
& $\mathbf{N}$ & 1045 & 1045 \\
\hline Hope & Pearson Correlation & $0,400^{* *}$ & 1 \\
& Sig. (2-tailed) & 0,000 & 1045 \\
\hline * correlation is significant at the 0.01 level (2-tailed) & 1045 &
\end{tabular}

\section{DISCUSSION}

The major finding from the present research is that Islamic construct hope is strongly correlated with mental well-being. This finding is supported with the empirical study of (Davidson-arad et at. 2013) which indicated that hope correlate with social support, good family parenting and self esteem. These three attributes are seen as components of mental well being. Equally, in 2006, Kylma et al. provided an integrative review of the current status of research on hope and schizophrenia, using content analysis to examine 17 relevant published articles. Findings indicated that hope is a positive factor in the lives of individuals living with schizophrenia, their significant others, and their healthcare personnel. In addition to identifying factors associated with and contributing to hope in individuals living with schizo- phrenia, Kylma et al. identified hope engendering interventions and treatment evaluation with regard to hope for this population (Esteves et al. 2013).
In addition (Feldman \& Kubota 2015) conducted a quantitative research to test a path-analytic model where academicspecific expectancies (e.g., academic hope, academic self-efficacy) have direct paths to GPA, and generalized expectancies (e.g. general hope, general self-efficacy) have paths to these Academic specific variables. In a cross-sectional sample of 89 college students, the Hope Scale was administer in the domain of Specific Hope Scale (academic subscale), General Self-Efficacy Scale, Academic Self-Efficacy Scale, Life Orientation Test-Revised (optimism), among others. The result show that a modified version of the hypothesized model demonstrated good fit. Generalized hope predicted academic-specific hope and academic self-efficacy, both of which then predicted GPA. All these show that the result of the present research is in line with the established literatures. Theref ore it can be concluded that the Islamic construct Hope is strongly related with mental well being. 
Uswatun Hasanah, Sri Nurul Milla dan Ismail Abdul Fatai

\section{CONCLUSION}

The major implication of the present research is the Muslim psychiatrists, clinicians, psychologists and counselors can rely solely on the Islamic construct hope for their therapeutic intervention for their Muslim clients. This will enable the Muslim patients to respond positively to their treatment due to the fact that they would be treated with what they are familiar with hopefully it can ease the process of the intervention and enable quick recovery.

\section{REFERENCES}

Al-Ghazzali, M. B. (n.d). thya "Ulumuddin (The Revival of Religious Sciences) (Volume 3). Beirut: Dar lhya alKutub al-,,lmilyyah.

Bonney, S., Stickley, T, 2008. Recovery and mental health: a review of the British literature.

Journal of Psychiatry and Mental Health Nursing 15, 140-153.

Creswell, W.J. (2012). Educational research: planning, conducting and evaluating quantitative and qualitative research $\left(4^{\text {th }}\right.$ edn.).

Davidson-arad, B. et al., 2013. Children and Youth Services Review Comparison of hope of maltreating parents whose children were removed from home with those whose children were kept at home. Children and Youth Services Review, 35(12), pp.2040-2048. Available at http://dx.doi.org/ 10.1 016/j.childyouth.2013.09.011.

Esteves, $M_{1}$ et $\mathrm{al}_{\mathrm{l}_{4}}$ 2013. An integrative review of adolescent hope. Journal of Pediatric Nursing, 28(2), 105-113. Available at: http://dx.doi.org/10.1016/j.pedn.20 12.03.033.

Feldman, D.B. \& Kubota, M., 2015. Hope , self-ef fi cacy, optimism, and academic achievement: Distinguishing constructs and levels of speci fi city in predicting college grade-point average मr. Learning and Individual Differences, 37, 210216. Available at: http://dx.doi.org/10.1016/j.lindif .20 14.11.022.

Hasson-ohayon, l. et al, 2009. A path for women coping with a diagnosis of breast cancer. Psychosomatics, 50(5), pp.525-533. Available at: http://dx.doi.org/10.1016/S00333182(09)70846- 1 .

Gorsuch, R.L., \& McPherson, S.E. (1989). Intrinsic/extrinsic measurement: I/E-Revised and single-item scales. Journal for the Scientific Study of Religion, 28(3), $348-354.2$. doi:10.1186/1477-7525-11-2

Hasson-Ohayon, L., Kravetz, S., Meir, T, Rozencwalg, S, 2009. Insight into severe mental iliness, hope, and quality of life on persons with schizophrenia and schizoaffective disorders. Psychiatry Research, 167. 231-238.

Holdcraft, C., Williamson, C., 1991. Assessment of hope in psychiatric and chemically dependent patients. Applied Nursing Research, 4, 129134

Kashdan, T, B, Pelham, W. E., Lang, A.R., 
Hoza, B, Jacob, R. G., Jennings, J. R, et al. 2002.

Hope and optimismas human strengths in parents of chiidrenwith externalizing dis-orders: Stress is in the eye of the beholder. Journal of Social \&Clinical Psychology, 21,441-468. http://dx.doi.org/10.1521/jscp.21.4. 441.22597 .

Kyima, J., 2005. Dynamics of hope in aduits iiving with HIV/AIDS: a substantive theory. Journal of Advanced Nursing $52,620-630$.

Kylma, J. Juvakka, T. Nikkonen, $M$, Kofhonen, T, \& isohanni, M (2006). Hope and schizophrenia: An integrative review. Journal of Psychiatric and Mental Health Nursing, 13, 651-664

Kylma, J, Duggleby, W, Cooper, D, \& Moiandef, G. (2009). Hope in palliative cafe: An integrative review. Palliative \& Supportive Care, 7, 365377.

Lundgf en-Nilsson, $\AA$, Jonsdottir, I. H. Ahlborg, G, \& Tennant, A. (2013). Construct vaiidity of the Psychological General Weil Being Index (PGWBI) in a sampie of patients undergoing treatment for stress-related exhaustion: a Rasch anaiysis. Health and Quality of Life Outcomes, 11,

Moofe, S. L. (2005). Hope makes a difference. Journal of Psychiatric and Mental Health Nursing, 12, 100-105.

Ong A. D., Edwards, L. M. \& Bergeman, C S. (2006). Hope as a source of resilience in later adulthood. Personality and Individual
Differences, 41(7), $1263 \mathrm{e} 1273$.

Pfeifer, S. \& Waelty, U. (1995). Psychopathoiogy and religious commitment-a controlied study. Psychopathology, 28, 70-77.

Sekaran, U \& Bougie, R. (2010). Research Methods For Business: A Skill Building Approach. 5th Edition. UK: John Willey \& Sons, Ltd.

Schrank, B, Stanghellini, G., Slade, M., 2008. Hope in psychiatry: a review of the literatufe. Acto Psychiatrica Scandinavica, 118, 421-433

Schrank, B et ai., 2012. Social Science \& Medicine Determinants, selfmanagement strategies and interventions for hope in people with mental disorders: Systematic search and narrative review. Social Science \& Medicine, 74(4), pp.554-564. Available at: http://dx.doi.org/10.1016/j.socscim ed.2011.11.008.

Snyder, C R,Harris, C.,Anderson, J.R.,Holleran, S. A., Irving, L.M., Sigmon, S T., etal. (1991). The will and the ways: Deveiopment and vaiidation of an individualdifferences measure of hope. Journal of Personality and Social Psychology. $60,570-585$.

Snydef, C R, Sympson, S. C., Ybasco, F. C, Borders, T. F, Babyak, M. A, \& Higgins, R L. (1996). Development and validation of the State Hope Scaie. Journal of Personality and Sociol Psychology, 70(2), 321-335

Van Gestel-Timmermans, $\mathrm{H}_{\text {, }}$ Van Den Bogaard, J., Brouwefs, E, Herth, K., \& Van Nieuwenhuizen, C (2010). Hope 
Uswatun Hasanah, Sri Nurul Milla dan Ismail Abdul Fatai

as a determinant of mental health recovery: a psychometric evaluation of the Herth Hope index-Dutch version. Scanding-vian journal of Coring Sciences, 24[24], 67e74.
Werner, S, 2012. Subjective well-being , hope, and needs of individuals with serious mental illness. Psychiatry Research, 196(2-3).pp.214-219. Available at: http://dx.doi.org/10.1016/i.psychre s.2011.10.012. 